\title{
PENGARUH PROGRAM DIABETES SELF MANAGEMENT EDUCATION BERBASIS KELUARGA TERHADAP KUALITAS HIDUP PENDERITA DIABETES MELITUS TIPE II DI WILAYAH KERJA PUSKESMAS MANGASA KOTA MAKASSAR
}

The influence of family-based Diabetes Self Management Education program on the quality of life of people with type II diabetes mellitus in the working area of Mangasa community health center Makassar

\author{
, Alfi Syahar Yakub', Dyah Ekowatiningsih ${ }^{2}$, Hartati3, Lia Reski Analia ${ }^{4}$ \\ Poltekkes Kemenkes Makassar \\ liareskianalia@gmail.com
}

\begin{abstract}
Diabetes Self Management Education aims to support decision making, self-care behavior, problem solving and active collaboration with health teams to improve clinical outcomes, health status and quality of life. Because diabetes is one of the chronic diseases, arising saturation or boredom in the patient regarding the schedule of previous treatment, so that patients do not regularly seek treatment therefore to overcome this need action against psychological factors in solving DM problems. Participation of other family members in guiding medication, diet, physical exercise and filling spare time is positive for family health. The design of this study was quasi experiment with non-equaivalent control group design with pre and post test design with sample size of 23 type II DM patients where 13 patients were intervention group and 10 control group patients. This study used wilcoxon and mann-whitney test. The results of this study indicate the score of family support before self management education 59,91 (SD $\pm 20,73)$ after intervention. The results showed that there was a difference of family support before and after intervention $(p=0.02)$. This shows there is influence of Self management education to support family in patient type DM II. Quality of life score before self management education 68,56 (SD $\pm 5,51$ ), increased to 82,26 (SD $\pm 12,14$ ) after intervention. The results showed that there was a difference in quality of life before and after intervention $(p=0.000)$. This shows there is influence of self management education on quality of life in patients with type II DM.
\end{abstract}

Keywords: Self management education, Family support, quality of life

\begin{abstract}
ABSTRAK
Diabetes Self Management Education bertujuan untuk mendukung pengambilan keputusan, perilaku perawatan diri, pemecahan masalah dan kolaborasi aktif dengan tim kesehatan untuk memperbaiki hasil klinis, status kesehatan dan kualitas hidup. Karena diabetes merupakan salah satu penyakit kronik,timbul kejenuhan atau bosan pada pasien mengenai jadwal pengobatan terdahulu, sehingga pasien tidak teratur berobat oleh karena itu untuk mengatasi hal ini perlu tindakan terhadap faktor psikologis dalam penyelesaian masalah DM. Keikutsertaan anggota keluarga lainnya dalam memandu pengobatan, diet, latihan jasmani dan mengisi waktu luang yang positif bagi kesehatan keluarga. Desain dalam penelitian ini quasi experiment dengan rancangan Non equaivalent control groupdengan pre and post test design dengan jumlah sampel 23 pasien DM tipe II dimana 13 pasien adalah kelompok intervensi dan 10 pasien kelompok kontrol. Penelitian ini menggunakan uji wilcoxon dan mann-whitney. Hasil penelitian ini menunjukkan skor dukungan keluarga sebelum self management education 59,91 ( $S D \pm 20,73)$ setelah dilakukan intervensi. Hasil analisis menunjukkan ada perbedaan dukungan keluarga sebelum dan setelah dilakukan intervensi $(p=0,02)$. Hal ini menunjukkan ada pengaruh Self management education terhadap dukungan keluarga pada pasien DM tipe II. Skor kualitas hidup sebelum self management education 68,56 $(S D \pm 5,51)$, mengalami peningkatan menjadi 82,26 $(S D \pm 12,14)$ setelah dilakukan intervensi. Hasil analisis menunjukkan ada perbedaan kualitas hidup sebelum dan setelah dilakukan intervensi $(p=0.000)$. Hal ini menunjukkan ada pengaruh self management education terhadap kualitas hidup pada pasien DM tipe II.
\end{abstract}

Kata Kunci : Self management education, Dukungan keluarga , kualitas hidup.

\section{PENDAHULUAN}

Diabetes Melitus (DM) adalah penyakit gangguan dalam metabolisme karbohidrat, lemak, dan protein sehingga kadar darah cenderung mengalami peningkatan yang diakibatkan oleh kerusakan sintesis pada sel beta pankreas atau pengeluaran insulin, atau ketidakmampuan jaringan dalam menggunakan insulin (Grossman, et.al,2014). Diabetes Melitus tipe II terjadi apabila produksi insulin tidak mencukupi atau tubuh tidak dapat menggunakan insulin secara memadai. Keadaan ini disebut resistensi insulin. Bila produksi insulin tidak cukup atau insulin tidak digunakan sebagaimana mestinya oleh jaringan-jaringan tubuh, 
gula (glukosa) tidak bisa masuk kedalam sel-sel tubuh. Saat glukosa menumpuk dalam darah, sel-sel tubuh tidak dapat berfungsi dengan baik (WHO,2011). Salah satu upaya yang dapat diterapkan adalah program Diabetes Self Management Education (DSME). DSME merupakan suatu proses berkelanjutan yang dilakukan untuk menfasilitasi pengetahuan, keterampilan, dan kemampuan klien Diabetes Melitus untuk melakukan perawatan mandiri (Funnel,et al, 2011). DSME bertujuan untuk mendukung pengambilan keputusan, perilaku perawatan diri, pemecahan masalah dan kolaborasi aktif dengan tim kesehatan untuk memperbaiki hasil klinis, status kesehatan, dan kualitas hidup (Haas, et al,2012). DSME menggunakan metode pedoman, konseling, dan intervensi perilaku untuk meningkatkan pengetahuan mengenai diabetes dan meningkatkan keterampilan individu dan keluarga dalam mengelolah penyakit DM (Jack et al.2004). Pendekatan pendidikan kesehatan dengan metode DSME tidak hanya sekedar menggunakan metode penyuluhan baik langsung maupun tidak langsung namun telah berkembang dengan mendorong partisipasi dan kerjasama diabetisi dan keluarganya.(Glassgow \& Anderson, 1999). Menurut Badruddin et al. (2002: 99-102.), diabetisi yang diberikan pendidikan dan pedoman dalam perawatan diri akan meningkatkan pola hidupnya yang dapat mengontrol gula darah dengan baik. Selan itu, pendidikan kesehatan yang diberikan akan lebih efektif bila petugas kesehatan mengenal tingkat pengetahuan, sikap dan kebiasaan sehari-hari pasien dan keluarga tersebut. Pendidikan kesehatan yang sesuai kebutuhan pasien dan keluarga, secara langsung atau tidak langsung dapat meningkatkan kemampuan perawatan secara mandiri sehingga produktifitas pasien dan keluarganya dapat meningkat juga. Melalui pelibatan keluarga dalam program Diabetes Self Management Education ini diharapkan dapat meningkatnya kepatuhan perawatan yang dilakukan oleh pasien DM sehingga berdampak pada peningkatan kualitas hidupnya. Pengobatan untuk penyakit Diabetes Melitus itu sendiri memerlukan waktu yang lama yaitu seumur hidup dan tidak hanya pengobatan saja yang harus dilakukan oleh penderitanya, namun juga gaya hidup yang harus dikontrol membuat penderita Diabetes Melitus terkadang mengalami putus asa dan dapat mempengaruhi kualitas hidupnya. Kualitas hidup sangat dibutuhkan untuk individu yang menderita Diabetes Melitus dalam proses pengobatan, agar individu tersebut lebih memperhatikan bagaimana meningkatkan kualitas hidupnya untuk dapat mencapai kondisi fisik yang lebih baik lagi dan menurunkan tingkat keparahan dari penyakit yang dideritanya tersebut. Berdasarkan data yang diperoleh dari Puskesmas Mangasa Kota Makassar pada tahun 2015 jumlah penderita Diabetes
Melitus 60 orang dan pada tahun 2016 terdapat 821 orang penderita dan pada tahun 2017 penderita diabetes berjumlah 903 orang dimana ada 3 kelurahan yang berkunjung di Puskesmas Mangasa.

Berdasarkan hal tersebut di atas, maka penulis tertarik membuat penelitian dengan judul "Pengaruh Program Diabetes Self Management Education Berbasis Keluarga Terhadap Kualitas Hidup Penderita Diabetes Melitus Tipe II di wilayah Puskesmas Mangasa".

\section{METODE PENELITIAN}

\section{Desain, waktu dan tempat \\ Penelitian ini merupakan penelitian menggunakan quasi experiment dengan rancangan Non equaivalent control group dengan pre and post test design. Pada penelitian ini terdapat 2 kelompok yaitu 1) kelompok eksperimental diberi perlakuan berupa edukasi dengan pendekatan prinsip DSME berbasis keluarga 2) kelompok kontrol mendapatkan perlakuan seperti biasa. Pada kedua kelompok dilakukan pre test dan post test. Populasi dalam penelitian ini adalah penderita DM tipe II yang melakukan kunjungan di Puskesmas Mangasa kota Makassar. \\ Jumlah dan cara pengambilan subjek atau bahan dan alat}

Populasi penderita Diabetes Melitus yang berkunjung sebanyak 903 dalam 3 kelurahan. Sampel adalah seluruh pasien DM tipe II yang termasuk dalam kriteria inklusi dan berada pada saat penelitian berlangsung selama 1 bulan serta berada di wilayah kerja Puskesmas Mangasa kota Makassar. Sampel diambil secara aksidental sampling.

\section{HASIL}

Penelitian dilaksanakan di Wilayah Puskesmas Mangasa Kota Makassar, dalam bentuk pengambilan data dari tanggal 20 - 27 April 2018, melalui penyebaran kuesioner kepada responden dan lembar persetujuan sebagai responden. Banyaknya sampel dalam peneltian ini 23 responden. Sebelum pengisian kuesioner dan lembar persetujuan peneliti menjelaskan tentang tata cara pengisian dari jawaban pasien. 
Tabel 5.1

Karakteristik Jenis Kelamin Responden di Puskesmas Mangasa Makassar $(n=23)$
Tabel 5.2

Distribusi Umur Responden Berdasarkan Kelompok di Puskesmas Mangasa Makassar $(n=23)$

\begin{tabular}{|c|c|c|c|c|c|c|}
\hline \multirow[t]{2}{*}{$\begin{array}{l}\text { Karakteristik } \\
\text { Responden }\end{array}$} & \multicolumn{2}{|c|}{$\begin{array}{c}\text { Kelompok } \\
\text { Intervensi } \\
(n=13)\end{array}$} & \multicolumn{2}{|c|}{$\begin{array}{c}\text { Kelompok } \\
\text { Kontrol } \\
(n=10)\end{array}$} & \multicolumn{2}{|c|}{ Total } \\
\hline & n & $\%$ & $\mathrm{n}$ & $\%$ & $\mathrm{n}$ & $\%$ \\
\hline Jenis Kelamin & & & & & & \\
\hline Laki-Laki & 2 & 28,6 & 5 & 71,4 & 11 & 100 \\
\hline Perempuan & 11 & 68,8 & 5 & 31,2 & 4 & 100 \\
\hline
\end{tabular}

Tabel 5.1 menunjukkan bahwa, kelompok kontrol lebih banyak berjenis kelamin laki-laki yaitu sebanyak 5 orang $(71,4 \%)$, sedangkan kelompok intervensi sebagian besar berjenis kelamin perempuan yaitu 11 orang $(68,8 \%)$.

\begin{tabular}{ccccccc}
\hline $\begin{array}{c}\text { Karakteristi } \\
\text { kumur } \\
\text { responden }\end{array}$ & $\mathrm{N}$ & Mean & $\begin{array}{c}\text { Med } \\
\text { ian }\end{array}$ & SD & $\begin{array}{c}\text { Min-M } \\
\text { ak }\end{array}$ & $95 \% \mathrm{Cl}$ \\
\hline $\begin{array}{c}\text { Kelompok } \\
\text { Intervensi }\end{array}$ & 13 & 51,69 & 51 & 7,59 & $40-63$ & $\begin{array}{c}47,10-5 \\
6,28\end{array}$ \\
\hline $\begin{array}{c}\text { Kelompok } \\
\text { Kontrol }\end{array}$ & 10 & 58,00 & 60 & 8,23 & $43-68$ & $\begin{array}{c}52,11-63 \\
, 88\end{array}$ \\
\hline
\end{tabular}

Tabel 5.2 menunjukkan bahwa rata-rata umur kelompok intervensi 51,69 tahun $(95 \% \mathrm{Cl}$ : 47,10-56,28) dengan standar deviasi 7,59 tahun. Umur paling muda 40 tahun dan paling tua 63 tahun. Hasil estimasi interval dapat disimpulkan bahwa rata-rata umur kelompok intervensi yaitu 47,10-56,28 tahun.

Rata-rata umur kelompok kontrol lebih tua yaitu 58,00 tahun $(95 \% \mathrm{Cl}: 52,11-63,88)$ dengan standar deviasi 8,23. Umur paling muda 43 tahun dan paling tua 68 tahun Hasil estimasi interval dapat disimpulkan bahwa $95 \%$ diyakini rata-rata umur kelompok kontrol yaitu $52,11-63,88$ tahun.

Tabel 5.3

Distribusi Dukungan Keluarga Responden Sebelum dan Setelah Self Management Education di Puskesmas Mangasa

Makassar $(n=23)$

\begin{tabular}{llll}
\hline \multicolumn{1}{c}{ Dukungan Keluarga } & $\begin{array}{c}\text { Kelompok Intervensi } \\
(\mathrm{n}=13)\end{array}$ & $\begin{array}{c}\text { Kelompok Kontrol } \\
(\mathrm{n}=10)\end{array}$ & \multicolumn{1}{c}{$\begin{array}{c}\text { Total } \\
(\mathrm{n}=23)\end{array}$} \\
\hline Sebelum Intervensi & & & \\
Mean (SD) & $58,61(7,20)$ & $61,60(7,45)$ & $59,91(7,30)$ \\
Median & 58,00 & 63,00 & 61,00 \\
Min - Max & $46-70$ & $46-71$ & $46-71$ \\
$95 \% \mathrm{Cl}$ & $56,26-66,93$ & $56,75-63,07$ \\
\hline Setelah Intervensi & $54,26-62,96$ & & \\
Mean (SD) & $59,60(3,83)$ & $82,17(20,73)$ \\
Median & $99,53(5,05)$ & 58,50 & 92,00 \\
Min - Max & 101,00 & $56-69$ & $56-105$ \\
$95 \% \mathrm{Cl}$ & $88-105$ & $56,85-62,34$ & $73,20-91,13$ \\
\hline
\end{tabular}

Tabel 5.3 menunjukkan bahwa rata-rata dukungan keluarga kelompok intervensi sebelum dilakukan self management education adalah 58,61 (Cl 95\%: $54,26-62,96)$, dengan standar deviasi 7,20 . Sedangkan pada kelompok kontrol $61,60(56,26-66,93)$ dengan standar deviasi 7,45. Skor terendah ditemukan pada kelompok intervensi maupun kelompok kontrol yaitu 46 dan tertinggi pada kelompok kontrol yaitu 71. Hasil estimasi interval dapat disimpulkan bahwa 95\% diyakini skor dukungan keluarga sebelum dilakukan self management education 56,75-63,07.

Setelah dilakukan self management education, rata-rata skor dukungan keluarga lebih tinggi pada kelompok intervensi yaitu 99,53 (SD $\pm 5,05)$ sedangkan pada kelompok kontrol 59,60 (SD $\pm 3,83)$. Skor dukungan keluarga terendah ditemukan pada kelompok kontrol 
yaitu 56 sedangkan skor dukungan keluarga tertinggi pada kelompok intervensi yaitu 105. Hasil estimasi interval dapat disimpulkan bahwa 95\% diyakini skor dukungan keluarga setelah dilakukan self management education 73,20-91,13 dilakukan self management education, rata-rata skor kualitas hidup lebih tinggi pada kelompok intervensi yaitu 91,53 $(\mathrm{SD} \pm 7,06)$ sedangkan pada kelompok kontrol 70,20 (SD $\pm 2,85)$. Skor kualitas hidup terendah ditemukan pada kelompok kontrol yaitu 70 sedangkan skor kualitas hidup tertinggi pada kelompok intervensi yaitu 100. Hasil estimasi interval dapat disimpulkan bahwa 95\% diyakini skor kualitas hidup setelah dilakukan self management education $77,00-87,51$.

Tabel 5.4

Distribusi Kualitas Hidup Responden Sebelum dan Setelah Self Management Education di Puskesmas Mangasa Makassar $(n=23)$

\begin{tabular}{llll}
\hline \multicolumn{1}{c}{ Kualitas Hidup } & \multicolumn{1}{c}{$\begin{array}{c}\text { Kelompok Intervensi } \\
(\mathrm{n}=13)\end{array}$} & \multicolumn{1}{c}{$\begin{array}{c}\text { Kelompok Kontrol } \\
(\mathrm{n}=10)\end{array}$} & \multicolumn{1}{c}{$\begin{array}{c}\text { Total } \\
(\mathrm{n}=23)\end{array}$} \\
\hline Sebelum Intervensi & & & $68,56(5,51)$ \\
Mean (SD) & $67,84(3,71)$ & $69,50(7,36)$ & 68,00 \\
Median & 67,00 & 68,00 & $61-88$ \\
Min - Max & $61-75$ & $62-88$ & $66,17-70,95$ \\
$95 \% \mathrm{Cl}$ & $65,60-70,09$ & $64,22-74,77$ & \\
\hline Setelah Intervensi & & & \\
Mean (SD) & $91,53(7,06)$ & $70,20(2,85)$ & $83,26(12,14)$ \\
Median & 94,00 & 70,00 & $67-100$ \\
Min - Max & $73-100$ & $67-77$ & $77,00-87,51$ \\
$95 \% \mathrm{Cl}$ & $87,26-95,80$ & $68,15-72,24$ & \\
\hline
\end{tabular}

\section{Hasil Analisis Inferensial}

Analisis inferensial digunakan untuk mengetahui perbedaan dukungan keluarga dan kualitas hidup antara kelompok kontrol dan kelompok intervensi sebelum dan setelah dilakukan self management education, serta mengetahui pengaruh self management education terhadap dukungan keluarga dan kualitas hidup

Tabel 5.5.

Perbedaan Dukungan Keluarga dan Kualitas Hidup sebelum dan Setelah Self Management Education pada Pasien DM Tipe II di Puskesmas Mangasa Makassar $(n=23)$

\begin{tabular}{lccc}
\hline \multicolumn{1}{c}{ Variabel } & $\begin{array}{c}\text { Sebelum self management } \\
\text { education }\end{array}$ & $\begin{array}{c}\text { Setelah self management } \\
\text { education }\end{array}$ & $P$ \\
\hline Dukungan Keluarga & $59,91(7,30)$ & $82,17(20,73)$ & $0,02^{*}$ \\
Kualitas hidup & $68,56(5,51)$ & $82,26(12,14)$ & $0,000^{*}$ \\
\hline
\end{tabular}

*Uji Wilcoxon

Tabel 5.5 menunjukkan rata-rata skor dukungan keluarga sebelum self management education 59,91 $(\mathrm{SD} \pm 7,30)$, mengalami peningkatan menjadi 82,17 $(\mathrm{SD} \pm 20,73)$ setelah dilakukan intervensi. Hasil analisis menggunakan uji Wilcoxon menunjukkan ada perbedaan dukungan keluarga sebelum dan setelah dilakukan intervensi $(p=0.02)$. Hal ini menunjukkan ada pengaruh self management education terhadap dukungan keluarga pada pasien DM tipe II.

Rata-rata skor kualitas hidup sebelum self management education 68,56 (SD $\pm 5,51)$, mengalami peningkatan menjadi 82,26 $(S D \pm 12,14)$ setelah dilakukan intervensi. Hasil analisis menggunakan uji Wilcoxon menunjukkan ada perbedaan kualitas hidup sebelum dan setelah 
Tabel 5.6

Perbedaan Dukungan Keluarga antara Kelompok Kontrol dan Intervensi Sebelum dan Setelah Self Management Education pada Pasien DM Tipe II di Puskesmas Mangasa Makassar ( $\mathrm{n}=23$ )

\begin{tabular}{|c|c|c|c|c|c|}
\hline \multirow{2}{*}{\multicolumn{3}{|c|}{ Dukungan Keluarga }} & \multicolumn{2}{|c|}{ Kelompok } & \multirow[b]{2}{*}{$p$} \\
\hline & & & \multirow{2}{*}{$\begin{array}{c}\text { Intervensi }(n=13) \\
58,61(7,20)\end{array}$} & \multirow{2}{*}{$\begin{array}{c}\text { Kontrol } \quad(n=10) \\
61,60(7,45)\end{array}$} & \\
\hline $\begin{array}{l}\text { Sebelum } \\
\text { education }\end{array}$ & & management & & & $0.376^{*}$ \\
\hline $\begin{array}{l}\text { Setelah } \\
\text { education }\end{array}$ & self & management & $99,53(5,05)$ & $59,60(3,83)$ & $0.000^{*}$ \\
\hline
\end{tabular}

\section{* Uji Mann-Whitney}

Rerata skor dukungan keluarga pada kelompok intervensi setelah self management education adalah 99,53 dengan standar deviasi 5,05. Sedangkan skor dukungan keluarga pada kelompok kontrol 59,60 dengan standar deviasi 3,83. Hasil uji statistik disimpulkan ada perbedaan rata-rata skor dukungan keluarga antara kelompok kontrol dan kelompok intervensi setelah dilakukan self management education $(p=0,000)$.

Tabel 5.7

Perbedaan Kualitas Hidup antara Kelompok Kontrol dan Intervensi Sebelum dan Setelah Self Management Education pada Pasien DM Tipe II di Puskesmas Mangasa Makassar ( $\mathrm{n}=23$ )

\begin{tabular}{lccccc}
\hline & \multirow{2}{*}{ Kualitas Hidup } & \multicolumn{3}{c}{ Kelompok } & \multirow{2}{*}{$p$} \\
\cline { 3 - 4 } & & Intervensi $(\mathrm{n}=13)$ & Kontrol $(\mathrm{n}=10)$ & \\
\hline $\begin{array}{l}\text { Sebelum } \\
\text { seducation }\end{array}$ & self & management & $67,84(3,71)$ & $69,50(7,36)$ & $0.784^{*}$ \\
$\begin{array}{l}\text { Setelah } \\
\text { education }\end{array}$ & self & management & $91,53(7,06)$ & $70,20(2,85)$ & $0.000^{*}$ \\
\hline
\end{tabular}

* Uji Mann-Whitney

Rerata skor kualitas hidup pada kelompok intervensi setelah self management education adalah 91,53 dengan standar deviasi 7,06 . Sedangkan skor kualitas hidup pada kelompok kontrol 70,20 dengan standar deviasi 2,85. Hasil uji statistik disimpulkan ada perbedaan rata-rata skor kualitas hidup antara kelompok kontrol dan kelompok intervensi setelah dilakukan self management education $(p=0,000)$.

\section{PEMBAHASAN}

Penelitian ini responden memiliki umur rata-rata pada usia 40-63 tahun karena DM tipe II merupakan jenis DM yang paling banyak jumlahnya yaitu $90-95 \%$ dari seluruh penyandang DM dan banyak di alami oleh dewasa diatas 40 tahun. Hal ini disebabkan resistensi insulin pada DM tipe II cenderung meningkat pada lansia (40-65 tahun), riwayat obesitas dan adanya faktor keturunan (Smeltzer dan Bare, 2008). Hasil penelitian ini menunjukkan bahwa pada kelompok intervensi memiliki dukungan keluarga yang signifikan setelah diberikan DSME pada keluarga dan pasien sedangkan pada kelompok kontrol didapatkan dukungan keluarga yang tidak signifikan dikarenakan keluarga pasien tidak memiliki atau mendapatkan informasi yang tepat mengenai diabetes melitus sehingga pasien yang menderita diabetes tidak mendapatkan informasi yang tepat dari keluarga dan dukungan keluarga kurang. Pada kelompok intervensi pasien mendapatkan dukungan keluarga yang baik dikarenakan keluarga yang terlibat dalam penelitian ini adalah suami dan anak yang rata-rata berusai 17 - 45 tahun, sehingga informasi atau pengetahuan yang 
diberikan oleh peneliti lebih cepat diaplikasikan dalam kehidupan sehari-hari.

Dukungan keluarga yang diberikan adalah hal positif yang dapat membuat pasien lebih menjaga kesehatannya terutama pada penyakit diabetes. penelitian ini menunujukkan bahwa pada kelompok intervensi pasien mengalami peningkatan pada dukungan keluarga karena keluarga mengerti dan memiliki informasi yang tepat untuk tetap menjaga kesehatan pasien yang menderita diaabetes. Keluarga mengerti gejala yang dirasakan pasien pada saat mengalami masalah mengenai penyakitnya, mulai dari menyiapkan makanan diet bagi penderita diabetes, olahraga atau senam diabetes, mengontrol kadar gula darah, meminum obat secara teratur dan mengurangi strees yang mungkin dialami pasien karena diabetes. Sebelum dilakukan intervensi atau penyuluhan self management education keluarga pasien hanya mengingatkan untuk menghindari makanan pantangan atau keluarga melarang pasien makan makanan yang manis sesuai yang diketahui masyarakat bahwa penyakit diabetes melitus adalah penyakit gula.

Keluarga tidak terlalu memperhatikan psikologi pasien yang menderita diabetes seperti strees atau perasaan sedih ketika pasien mengalami sakit yang diderita, dan setelah dilakukan intervensi atau penyuluhan keluarga pasien mulai mengerti dan lebih memperhatikan keluarga. Keluarga biasanya mengajak pasien bercerita atau saling berbagi dengan apa yang diarasakan saat ini, dengan melakukan hal tersebut pasien merasa lebih diperhatikan, keluarga juga mulai menyiapkan makanan diet diabetes seperti makan nasi ( karbohidrat ) sesuai takaran tidak lagi seperti sebelumnya pasien memakan nasi dengan porsi 1 -2 piring dan memakai lauk indomie atau ubi .

Keluarga atau pasien tidak mengetaui bahwa makanan yang sering dikomsumsi dulu adalah hal yang harus dibatasi oleh penderita diabetes. Sekarang pasien memakan atau mengkomsumsi makanan sesuai diet diabetes lebih memperbanyak sayuran dan sudah mulai menjadwalkan jam makan dan makanan yang dikomsumsi. Keluarga dan pasien biasa melakukan olahrga atau senam di puskesmas atau melakukannya dirumah. Serta keluarga selalu mengingatkan pasien untuk minum obat teratur serta mengontrol kadar gula darah setiap satu bulan sehingga pasien dan keluarga dapat memantau gula darah pasien dalam batas normal.

Hasil penelitian ini dapat menunjukkan bahwa dukungan keluarga pasien mengalami peningkatan atau perubahan yang signifikan setelah dilakukan intervensi atau penyuluhan self management education berbasis keluarga.

Sebelum dilakukan intervensi atau penyuluhan pada pasien dan keluarga kualitas hidup pasien tidak terkontrol, pasien tahu bahwa dirinya mengalami penyakit diabetes tetapi pasien tetap memakan makanan pantangan diabetes atau makanan yang sesuai keinginannya, pasien juga jarang atau tidak mau melakukan olahrga/senam karena pasien malas bergerak, melakukan pemeriksaan gula darah tidak teratur kadang pasien memeriksakan gula darah jika ke puskesmas atau merasakan gejala hiperglikemia ( gula darah tinggi) atau hipoglikemia ( gula darah rendah) . Biasanya kadar gula darah pasien tidak terkontrol, rata-rata kadar gula darah pasien mengalami hiperglikemia karena pasien tidak mengontrol makanan yang dikomsumsi dan tidak meminum obat sesuai jadwal.

Setelah diberikan intervensi atau penyuluhan pasien lebih menjaga gaya hidup, pasien sudah mengerti hal-hal yang dapat membuat penyakit diabetes menjadi parah, melakukan diet diabetes, pasien sekarang memakan makanan seperti mengkomsumsi nasi (karbohidrat) dengan takaran mangkok kecil dan memperbanyak sayur beserta buah-buahan.menjadwalkan jam makan dan minum obat teratur. Pasien aktif mengikuti olahraga dan senam diabetes dipuskesmas Mangasa kota Makassar setiap hari sabtu, pasien merasa lebih sehat dan segar setelah melakukan senam, pasien juga melakukan olahraga seperti berjalan kaki sekitar 10 -20 menit. Setiap sebulan sekali pasien melakukan cek gula darah dipuskesmas sehingga pasien dapat mengetahui atau memantau kadar gula darahnya.

Setelah pasien mengaplikasikan hal yang telah diberikan oleh peneliti pasien merasakan perubahan atau merasa lebih sehat sehingga kualitas hidup pasien lebih baik. Pasien mulai merasa seperti orang sehat atau tidak memiliki penyakit diabetes. Hasil penelitian ini menunjukkan bahwa kualitas hidup pasien mengalami perubahan atau peningkatan yang signifikan setelah diberikan intervensi atau penyuluhan.

Sedangkan penelitian pada kelompok kontrol dukungan keluarga dan kualitas hidup diberikan kuesioner pre dan post tanpa diberikan penyuluhan diabetes self management education, dukungan keluarga dan kualitas hidup penderita diabetes melitus juga mengalami perubahan namun tidak signifikan sedangkan pada kelompok intervensi dukungan keluarga dan kualitas hidup pada penderita diabetes melitus mengalami perubahan jadi dapat disimpulkan bahwa dengan adanya pemberian penyuluhan diabetes self management education pada penderita diabetes melitus dapat memberikan perubahan dan pengaruh yang signifikan terhadap dukungan keluarga serta kualitas hidup penderita diabetes melitus tipe II diwilayah kerja puskesmas Mangasa kota Makassar. 
Dan pada kelompok kontrol kualitas hidupnya meningkat meskipun tidak signifikan karena pasien pada kelompok kontrol pasien juga sering mendapatkan informasi dari pihak puskesmas mengenai diabetes dan cara hidup sehat diabetes meskipun informasi yang diperoleh tidak seperti pada pasien kelompok intervensi

\section{KESIMPULAN}

Dukungan keluarga dan kualitas hidup penderita diabetes melitus pada kelompok intervensi mengalami perubahan atau memiliki pengaruh setelah diberikan penyuluhan diabetes self management education berbasis keluarga. Adanya perbedaan pada kelompok intervensi dan kelompok kontrol pada dukungan keluarga serta kualitas hidup penderita diabetes melitus tipe II sebelum dan sesudah diberikan penyuluhan diabetes self management education berbasis keluarga.

\section{SARAN}

1. Keluarga

Diharapkan agar dapat meningkatkan dukungan keluarga atau lebih memperhatikan keluarga yang menderita penyakit diabetes melitus agar dapat menjaga kesehatan, menghindari makanan pantangan, berolahraga dan meminum obat sesuai aturan atau pemberian insulin pada keluarga yang menderita diabetes melitus dan mengontrol kadar gula darah sehingga dapat meningkatkan kualitas hidup bagi penderita diabetes melitus.

\section{Pasien}

Diharapkan agar pasien dapat menerapkan apa yang telah diberikan dari penyuluhan diabetes self management education, menjalankan diet diabetes, melakukan olahraga, meminum obat teratur dan mengontrol kadar gula darah dalam batas normal sehingga kualitas hidup para penderita penyakit diabetes melitus dapat meningkat.

3. Peneliti selanjutnya

Diharapkan untuk dapat mengembangkan penelitian lebih lanjut berhubungan dengan pengaruh program diabetes diabetes self management education berbasis keluarga terhadap kualitas hidup pendeita Diabetes melitus tipe II.

\section{DAFTAR PUSTAKA}

Afrian, Niah Nuari. (2017). Strategi manajemen edukasi pasien diabetes mellitus. Yogyakarta: Deepublish.

Aji, Rangga Nur Wahid. (2016). Pengaruh pendidikan kesehatan diabetes self management education terhadap kadar gula darah pasien diabetes tipe II di prolanis Puskesmas Gajahan Surakarta. http://digilib.stikeskusumahusada.ac.id/download.php?id=1545. Diakses hari rabu, 31 Januari 2018 pukul 10.43 wita.

Arisman (2014). Obesitas, Diabetes Melitus \& Dislipidemia, Konsep, Teori, dan Penanganan Aplikatif. Jakarta : EGC

Aulia, Afriliana Firda. (2016). Pengaruh diabetes self management education (DSME) menggunakan diary si dm terhadap kualitas hidup penderita diabetes melitus (DM) tipe 2. http://repository.um-surabaya.ac.id/424/1/Pendahuluan.pdf. Diakses hari rabu, 31 Januari 2018 pukul 10.38 wita.

Basuki E. 2007. Teknik Penyuluhan Diabetes Melitus. Pusat Diabetes \& Lipid RSUP Nasional DR CiptomangunkusumoFKUI. Jakarta

Damayanti, Santi. (2015). Diabetes mellitus \& penatalaksanaan keperawatan. Yogyakarta: Nuha Medika

Diabetes self management education. https://www.professional.diabetes.org/diabetes-self-management-education. Diakses hari senin, 12 Januari (2018) pukul 20.18 wita.

Dinas Kesehatan Kota Makassar. (2016). Profil Kesehatan Kota Makassar Tahun 2016. Dipetik Februari 19, 2018, dari https://www.google.com/dinkeskotamakassar.com.Aprofil-dinas-kesehatan-2016

Fakultas kedokteran Universitas Indonesia. 2015. Penatalaksanaan diabetes mellitus terpadu. Jakarta: Balai Penerbit FKUI. 
Jurnal Media Keperawatan: Politeknik Kesehatan Makassar

Vol. 11. No. 012020

e-issn : 2622-0148, p-issn : 2087-0035

Faisol, Moh Al Fady. (2015). Madu dan luka diabetik metode perawatan luka komplementer dilengkapi dengan hasil riset. Yogyakarta: Gosyen Publishing.

Harnilawati. (2013). Konsep dan proses keperawatan keluarga. Takalar : Pustaka As Salam

Hasanah dkk. (2003). World Health Organization of life assessment. http:/le-mjm.org/2003 Iv58n1/WHO_Quality_of_Life_Assessment.pdf. diakses hari Senin, 12 Februari 2018 pukul 17.50 wita.

Isa B.A., \& Baiyewu, O. (2006). Quality of lifepatient with diabetes mellitus in a Nigerian Teaching Hospital. Hongkong Journal Psychiatry, 16, 27 - 33.

Karyadi E. 2006. Kiat Mengatasi Diabetes, Hiperkolesterolemia dan Stroke. PT Intisari Mediatama. Jakarta

Luthfa, Iskim. (2016). Family support pada penderita diabetes mellitus tipe 2 di Puskesmas Bangetayu Semarang, analisis rasch model. http://jurnal.unissula.ac.id/index.php/jnm/article/download/723/602. Diakses hari senin, tanggal 12 februari 2018 pukul 17.50 wita.

National standards for diabetes self-management education and support. (2017) http://care.diabetesjournals.org /content/diacare/early/2017/07/26/dci17-0025.full.pdf. Diakses hari senin, 12 Januari 2018 pukul 20.17 wita.

Notoadmojo, Soekidjo. 2011. Metodologi penelitian kesehatan. Jakarta : Rineka Cipta.

Nuari, Nian Afrian. 2017. Strategi manajemen edukasi pasien diabetes mellitus. Yogyakarta: deepublish

PERKENI. 2011. Konsensus Pengelolaan dan Pencegahan DM Tipe 2 di Indonesia. Penerbit PERKENI. Jakarta

Pusat data dan informasi kementerian kesehatan RI. (2014). Situasi dan analisis diabetes. http://www.depkes.go.id /resources/download/pusdatin/infodatin/infodatin-diabetes.pdf. Diakses hari sabtu 27 Januari (2018) pukul 11.12 wita.

Rahayu, Eva dkk. (2014). Pengaruh program diak If management education berbasis keluarga terhadap kualitas hidup penderita diabettes mellitus tipe II di wilayah Puskesmas II Baturaden. http://www.jurnal.unsyiah.ac.id IJIK/article/download/6320/5204. Diakses hari Sabtu 27 Januari 2018 pukul 09.10 wita.

Rahmawati dkk. (2016). Pengaruh program diabetes self-management terhadap manajemen diri pada penderita diabetes mellitus tipe 2. http://jks.fikes.unsoed.ac.id/index.php/jks/article/download/611/336. Diakses hari minggu, 28 Januari 2018 pukul 14.23 wita.

Raiyah, Sri Wahyuni. 2013. Pengaruh edukasi dengan pendekatan prinsip diabetes self management education (DSME) dalam meningkatkan perilaku kepatuhan diet pada penderita diabetes mellitus tipe I [skripsi]. Makassar (ID); Poltekkes Kemenkes Makassar.

Rondhianto. (2012). Pengaruh diabetes self management education dalam discharge planning terhadap self care behavior pasien diabetes mellitus tipe 2.http://iks.fikes.unsoed.ac.id/index.php/jks/article/download/400/227. Diakses hari sabtu, 27 Januari 2018 pukul 09.10 wita.

Suparyanto. Konsep dukungan keluarga. https://www.scribd.com/doc/185857958/Konsep-Dukungan-KeluargaDr-Suparyanto. diakses hari senin, 12 Januari 2018 pukul 21.25 wita.

Tandra.H (2013). Life Healthy With Diabetes, Diabetes Mengapa \& Bagaimana. Yogyakarta : Publishing.

WHO, (2018). The World Health Organization of life (WHOQOL). http://www.who.int/mental_health/publications Iwhogol/en. Diakses hari senin, 12 Februari 2018 pukul 17.50. 